\title{
Reproductive characteristics of a primitive bivalve from a deep-sea reducing environment: giant gametes and their significance in Acharax alinae (Cryptodonta: Solemyidae)
}

\author{
Peter G. Beninger ${ }^{1, *}$, Marcel Le Pennec ${ }^{2}$ \\ 'Laboratoire de Biologie Marine, Faculté des Sciences et des Techniques, Université de Nantes, F-44322 Nantes Cédex 3, France \\ ${ }^{2}$ Laboratoire de Biologie Marine, Université de Bretagne Occidentale, 29287 Brest Cedex, France
}

\begin{abstract}
Only 4 specimens of the cryptodont protobranch Acharax alinae have been found and collected to date, from the hydrothermal vent region of the Lau Basin (Fiji) in May 1989. The gonad organization and gametogenic cells of the 2 working specimens were investigated in the present study, using histology and transmission electron microscopy, in order to enhance our understanding of the reproductive biology of bivalves from deep-sea reducing habitats. The acini of the female were elongated and closely appressed to the ellipsoid-shaped mature oocytes, giving a tubular appearance. In both male and female the structural characteristics of the gametogenic cells were similar to those previously described for littoral species. The presence of female gametes in all stages of development suggests that spawning is continuous or at least repeatedly partial in this species. The mature female and male gametes were extraordinarily large: the equivalent spherical diameter for the mature oocytes was up to $600 \mu \mathrm{m}$; correction for fixation shrinkage would increase this size to approx. $660 \mu \mathrm{m}$. The mature spermatozoon presented a head+midpiece length of $28 \mu \mathrm{m}$ and a flagellum length of approx. $100 \mu \mathrm{m}$. These dimensions for the male and female gametes are, to our knowledge, the greatest ever reported for any bivalve species. As the pericalymma larva of the Solemyidae is a non-feeding stage, the large oocyte size is probably an adaptation for an extended lecithotrophic strategy, which would favour either long-range dispersal or protracted benthic development. The unusually elongated spermatozoon is probably a consequence of the large oocyte size. Its morphology is distinct from those of the other bivalve subclasses, which however do present species showing some spermatozoon head elongation or curvature. More generally, we suggest that spermatozoon morphology in bivalve taxonomy is most useful in groups with homogeneous developmental strategies.
\end{abstract}

KEY WORDS: Reproduction · Deep-sea $\cdot$ Acharax $\cdot$ Solemyidae $\cdot$ Gametes

\section{INTRODUCTION}

Although considerable attention has recently been directed to the feeding biology of organisms inhabiting deep-sea hydrothermal vents and cold seeps (see Cavanaugh 1985, Page et al. 1990. Tunnicliffe 1991, Childress \& Fisher 1992, and Le Pennec et al. 1995 for reviews and references), the reproductive biology of these organisms remains relatively obscure (Tunnicliffe 1991, Mullineaux \& France 1995). Investigations

•E-mail: beninger@svt.univ-nantes.fr of reproductive biology necessarily begin with the organization of the gonad and gametogenesis. The study of gametes allows insights into 2 fundamental areas: (1) From the gametogenesis and morphology of female gametes it is possible to deduce the nutritional strategy of early developmental stages (larvae). This is closely related to the amount of vitellus and size of the mature oocyte (Sastry 1979). (2) From the gametogenesis and morphology of male gametes it is possible to elucidate phylogenetic relationships with other taxa. The utility of spermatozoon characteristics for the study of phylogeny and taxonomy began to take root with 
the work of Franzen (1970), Popham (1979), Maxwell (1983) and Healy (1989). Interest in this concept has recently surged, with substantial progress in the understanding of phylogenetic relationships (for reviews, see Jamieson et al. 1995, Healy 1996). The morphology and ultrastructure of spermatozoa of deep-sea reducing environment fauna is particularly interesting, as the phylogenetic relationships among these organisms and with taxa from more conventional habitats remains obscure (Le Pennec \& Beninger 1997).

One of the least well-known species from the deepsea reducing habitats is the recently discovered protobranch Acharax alinae (Métivier \& von Cosel 1993) Only 4 adults of this Solemyidae have been recovered to date in the vicinity of hydrothermal vents; 2 are reference specimens at the Muséum National d'Histoire Naturelle in Paris, France, and 2 working specimens have been used in the present study.

Of the 2 orders (Solemyioida and Praecardidioida) of the subclass Cryptodonta, only 2 genera of Solemyioida survived beyond the Palaeozoic to the present: Solemya and Acharax. All of the Solemyioida discovered to date inhabit reducing environments and contain endosymbiotic bacteria. Twelve species have been assigned to the genus Acharax, of which 7 are found at depths greater than $900 \mathrm{~m}$. It is difficult to estimate their abundance, since they are deeply buried endobenthic organisms (Type 3 species from the standpoint of sulphide availability: Le Pennec et al. 1995), which until the 1989 Biolau expedition were only known by their shells, and in one case a single live specimen of the genus Acharax (see Métivier \& von Cosel 1993). Knowledge of the reproductive biology of this species would thus contribute to our understanding of the intriguing deep-sea reducing ecosystems

In this study we present the histological and ultrastructural characteristics of the gonad and gametes in Acharax alinae, including data on gametogenesis and the unusually large size of mature gametes.

\section{MATERIALS AND METHODS}

The specimens of Acharax alinae were obtained at $-1890 \mathrm{~m}$ using the IFREMER submersible 'Nautile' and mother ship 'Nadir', in May 1989 during the Biolau mission in the Lau Basin near the Fiji islands. The location of the sampling site, baptized 'Hine-Hina', was $22^{\circ} 32^{\prime} \mathrm{S}, 176^{\circ} 43^{\prime} \mathrm{W}$. At sampling, the specimens were buried in coarse sediment in proximity to a hydrothermal vent, although no temperature anomaly was recorded at the sampling site. The female specimen measured $91 \mathrm{~mm}$ and the male $102 \mathrm{~mm}$ along the antero-posterior axis. Upon arrival shipboard, the specimens were fixed whole in $10 \%$ formalin seawater. Two were retained as reference specimens at the Muséum National d'Histoire Naturelle, Paris, France, and 2 ( 1 male and 1 female) were transferred to the Laboratoire de Biologie Marine, Brest, France, Approx. $5 \mathrm{~mm}^{3}$ pieces of the gonad were dissected out and refixed in aqueous Bouin's medium and processed for paraffin histology, using the Goldner variation of the Masson trichrome staining procedure on $5 \mu \mathrm{m}$ sections. Small (1 to $2 \mathrm{~mm}$ ) pieces of the gonad were also dissected out and post-fixed in 3\% glutaraldehydesodium cacodylate buffer $(0.4 \mathrm{M}$, adjusted to 1300 mos $\mathrm{M}$ with $7 \% \mathrm{NaCl}, \mathrm{pH}$ 7.25). Previous studies had shown that while this procedure was not optimal, it did not induce distortion in sensitive structures such as mitochondria (Le Pennec \& Beninger 1997). The pieces were then rinsed in cacodylate buffer, dehydrated in an ascending ethanol gradient, embedded in Spurr resin, and cut using an ultramicrotome. Thin sections ( 1 to $2 \mu \mathrm{m}$ ) were stained with toluidine blue, while ultrathin sections $(100 \mathrm{~nm})$ were contrasted with uranyl acetate and lead citrate for transmission electron microscopy (TEM)

\section{RESULTS}

\section{Female gonad}

Two anatomical indices suggest that the acini of the female were greatly elongated and almost tubular: (1) the vitellogenic and mature oocytes were ellipsoid in shape, and (2) the germinal epithelium walls were closely appressed to these oblong yametes (Fig. 1.1-1.3). No reserve tissue was observed between the acini (Fig. 1.1. 1.2). Some oogonia (approx. $80 \mu \mathrm{m}$ diameter)

Fig. 1. Acharax alinae. Gonadal structure and details of female gametes. (1.1) General histological organization of the female gonad, showing vitellogenic oocytes (VO) within elongated acinal walls (AW). $1 \mu \mathrm{m}$ section, toluidine blue stain. (1.2) Detail of female gametes, showing oogonia (OG) adhering to acinal walls. $1 \mu \mathrm{m}$ semithin section, toluidine blue stain. (1.3, 1.4) Detail of vitellogenic oocytes, showing deep, tightly appressed folds of cell membrane in early vitellogenjc oocytes (arrowheads, EVO). and looser folds in late vitellogenic and mature oocytes (arrows, LVO, MO). Previtellogenıc oocytes (PVO) have round nuclei (N) and nucleoli (Nu). $1 \mu \mathrm{m}$ semithin sections, toluidine blue stain. (1.5) Very early, pedunculated oocytes (PO) adhering to acinal wall (AW), surrounded by vitellogenic oocytes (VO). $1 \mu \mathrm{m}$ semithin sections, toluidine blue stain. (1.6) Transmission electron micrograph detail of cellular inclusions in mature vitellogenic oocyte ( $\mathrm{L}$, lipid droplets; $\mathrm{V}$, vitellune inclusions) 

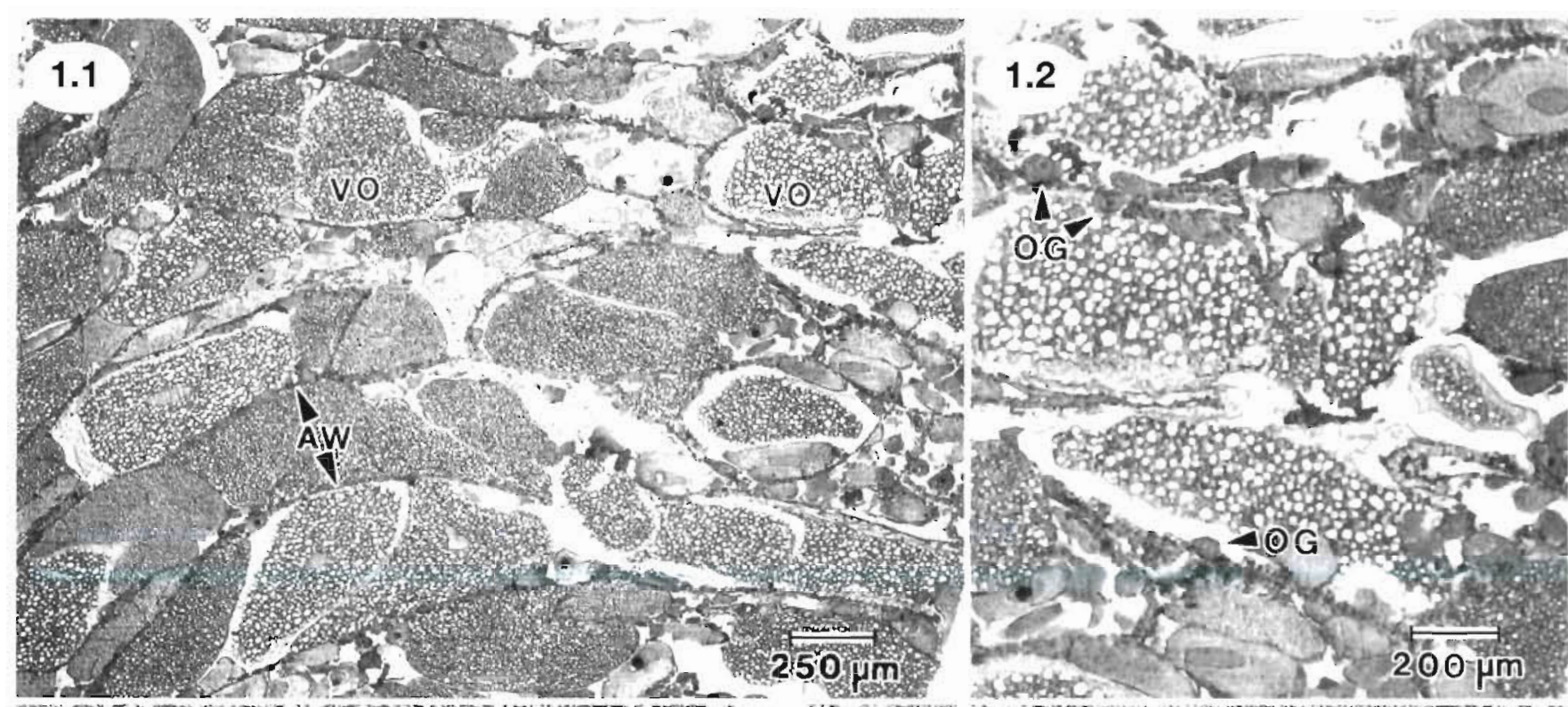

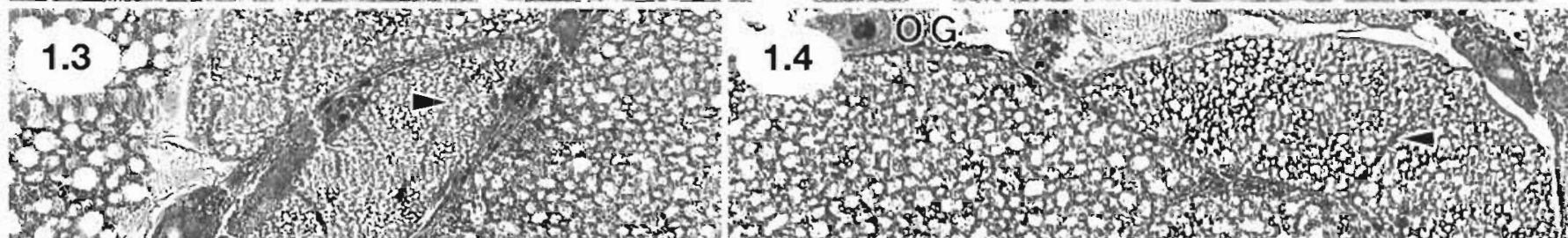

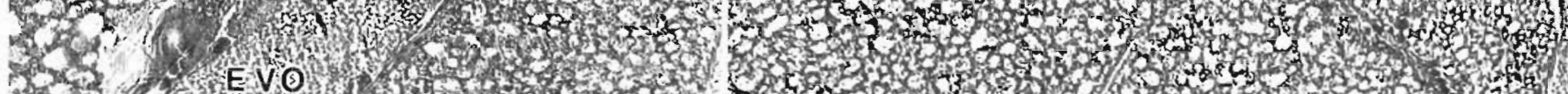

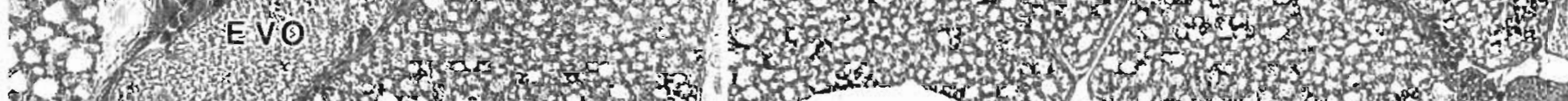

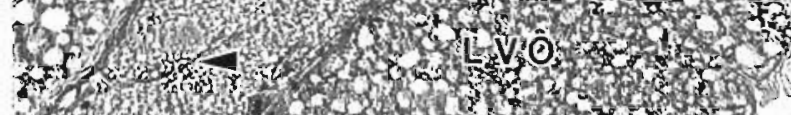

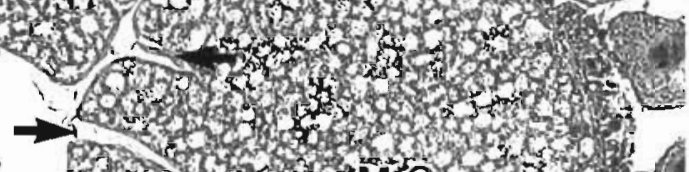

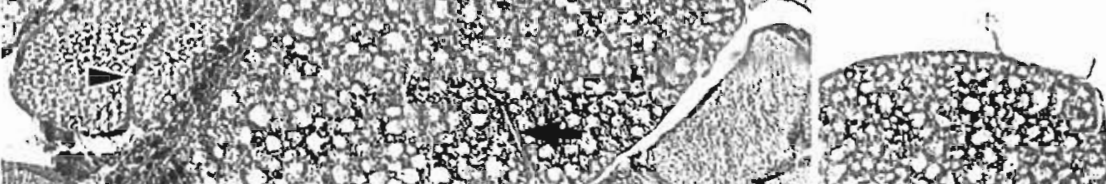

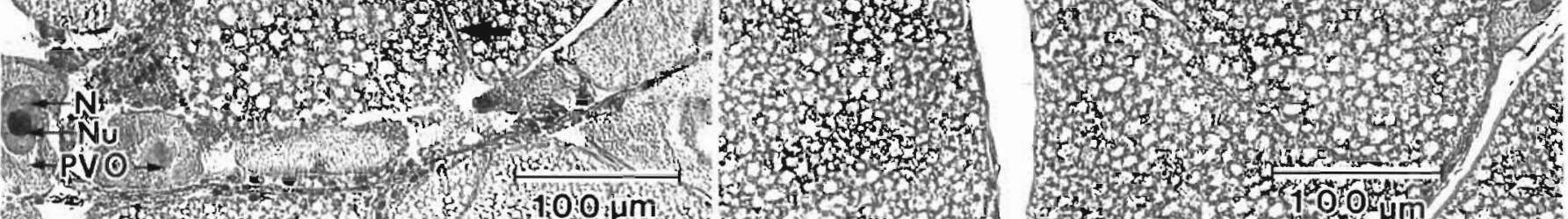
moth

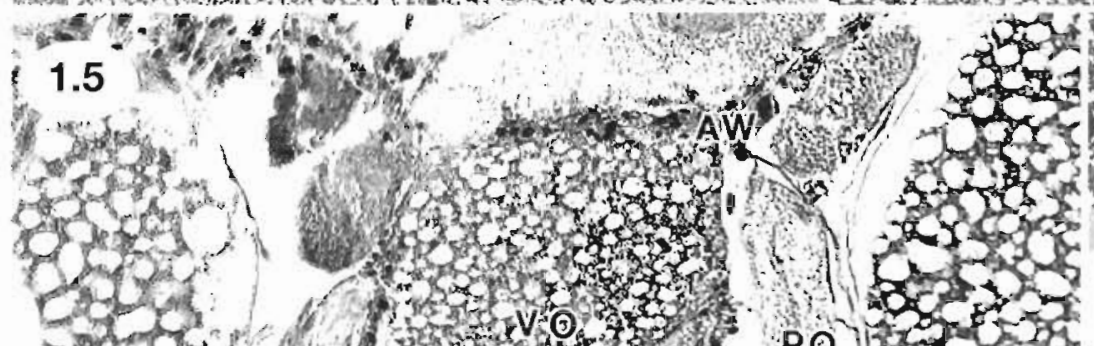

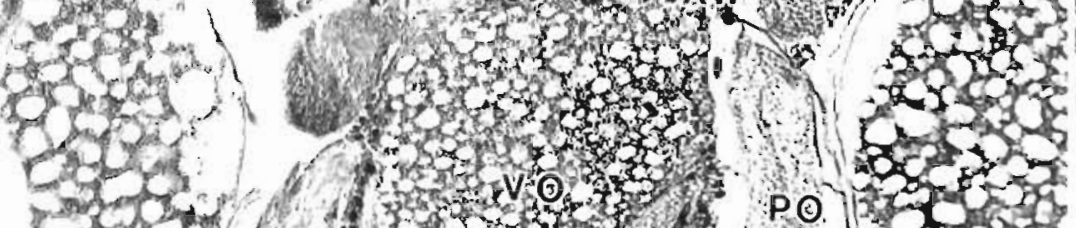
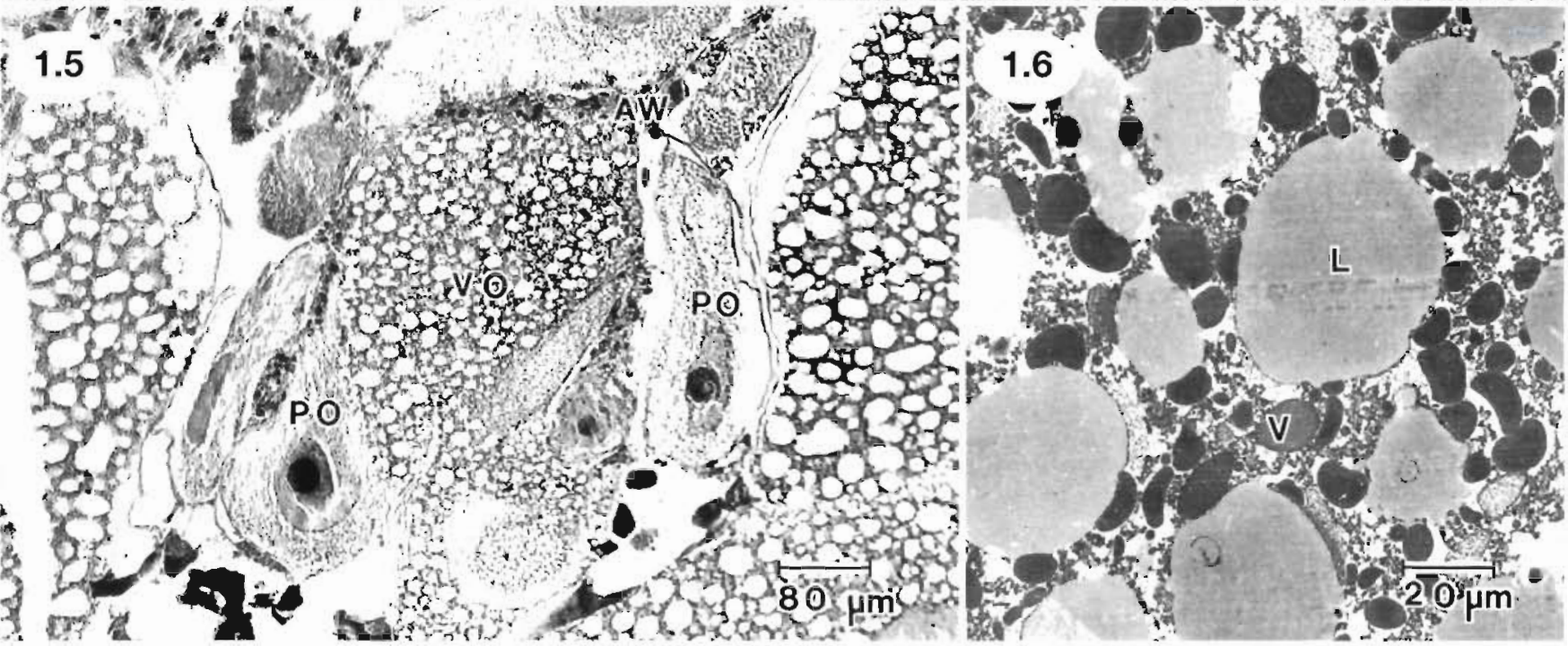
were observed adhering to the acinal walls, presenting a round nucleus and nucleolus (Fig. 1.2, 1.4). Both previtellogenic and vitellogenic oocytes were observed in the acini. The previtellogenic oocytes adhered to the acinal wall and measured approx. 80 to $130 \mu \mathrm{m}$ in diameter, with a round nucleus and nucleolus (Fig. 1.3). Early vitellogenic oocytes and their nuclei showed a tendency to elongation; late vitellogenic oocytes and their nuclei were markedly elongated (Fig. 1.3). These oocytes contained an abundant cytoplasm with numerous vitelline and lipid inclusions (Fig. 1.1-1.6). The largest of the vitellogenic oocytes measured $900 \times$ $400 \mu \mathrm{m}$ in longitudinal section. Deep, tightly appressed invaginations of the cell membrane were common in early vitellogenic oocytes, widening in later vitellogenic and mature oocytes (Fig. 1.3, 1.4).

Although no bacteria were observed in the female gametes at any stage, the resolution limits imposed by the fixation technique preclude any conclusive statement.

\section{Male gonad}

The male gonad lacked independent anatomical features which would allow definitive judgement concerning acinal elongation as seen in the female. The germinal epithelium was surrounded by loose connective tissue (Fig. 2.1), and progressively anastomosed and emptied into evacuating ducts comprising a pseudostratified ciliated epithelium (Fig, 2.2). The acini were lined with spermatogonia (diameter $7 \mu \mathrm{m}$ ), characterized by a relatively pale nucleus and cytoplasm when stained with Masson's trichrome (Fig. 2.3). The chromatin was clumped both in the interior of the nucleus and as a discontinuous border around the nuclear periphery (Fig. 2.5). Toward the lumen the following cell types were progressively encountered: spermatocytes, spermatids, and spermatozoa (Fig. 2.3, 2.4).

Several stages of primary spermatocytes (diameter approx. $5 \mu \mathrm{m}$ ) were readily visible (Figs. 2.5, 2.6 \& 3.1). The majority of these were in the first stage of prophase and located immediately adjacent to the spermatogonia, with chromatin more densely clumped than in the spermatogonia (Fig. 2.5). Toward the lumen, pachytene-stage cells were visible (Fig 2.6). No secondary spermatocytes were observed.

The spermatids were notably smaller than the spermatocytes, and depending on their stage of development and plane of section were either round (diameter approx. $3.5 \mu \mathrm{m}$ ) or oval (approx. $3.7 \times 2.2 \mu \mathrm{m}$ ) (Fig. 2.3 2.4). The chromatin was progressively more condensed in spermatids closer to the acinal lumen. In addition, the nucleus began to elongate, the acrosome began to form as a small cone, and the mitochondria migrated to the basal pole of the cell (Figs. 2.4 \& 3.2). Spermiogenesis continued with constitution of the single flagellum, further chromatin condensation, and an extreme elongation of both the nucleus and acrosome. The mature spermatozoon had a curved, rod-shaped head measuring 26 to $28 \mu \mathrm{m}$ from the tip of the acrosome to the base of the 4 mitochondria (diameter approx. $5 \mu \mathrm{m}$ each) constituting the midpiece (Fig. 3.3). The nucleus contained extremely dense and homogeneous chromatin, with rare vestiges of nucleoplasm; it measured approx. $19.6 \times 0.8 \mu \mathrm{m}$. The acrosome had the same width as the nucleus in its basal region, tapering to a point over its approx. $7 \mu$ m length. The acrosome was electron-transparent except for the distal extremity, which was notably more electronopaque, and the 2 small pyramidal loci at its basal region (Fig. 3.4)

Based on measurements of histological sections, the flagellae of mature spermatozoa were approx. $100 \mu \mathrm{m}$ in length. None of the TEM sections yielded the crosssectional views necessary for observation of microtubule arrangement within the flagellum. Similarly, the state of fixation precluded any definitive statements concerning the presence or absence of bacteria in the male gametes.

\section{DISCUSSION}

\section{Representativity}

The results of the present study rest upon data from only 1 individual of each sex. The recovery of addi-

Fig. 2. Acharax alinae. General male gonadal structure and gametogenic cell types. (2.1) Transverse section through acini (A) of a maturing gonad. Developing gametes (DG) are situated at the periphery, while mature spermatozoa (SZ) progressively fill the lumen (L). $5 \mu \mathrm{m}$ histological section, Masson's trichrome stain. (2.2) Junction of acinus and evacuating duct (ED). The acinus is partially filled with spermatozoa (SZ), with flagellae (FL) directed toward the lumen. $5 \mu \mathrm{m}$ histological section, Masson's trichrome stain. (2.3) Overview and histological appearance of gametogenic cells. SG, spermatogonia; SC, spermatocytes; ST, spermatids; SZ, spermatozoc. $5 \mu \mathrm{m}$ section, Masson's trichrome stain. (2.4) Transmission electron micrograph of gametogenic cells, showing spermatocytes (SC) with condensed, electron-dense nuclei and patches of electron-lucent nucleoplasm, early spermatids (ST), and elongated spermatids (EST). Note the appearance of the acrosome (A) in the elongating spermatid. (2.5) Transmission electron micrograph detall of the spermatogonia (SG) and primary spermatocytes (SC1). Note nuclear condensation in the spermatocyte. (2.6) Transmission electron micrograph of primary spermatocyte in pachytene stage of first meiotic prophase (SCP) 

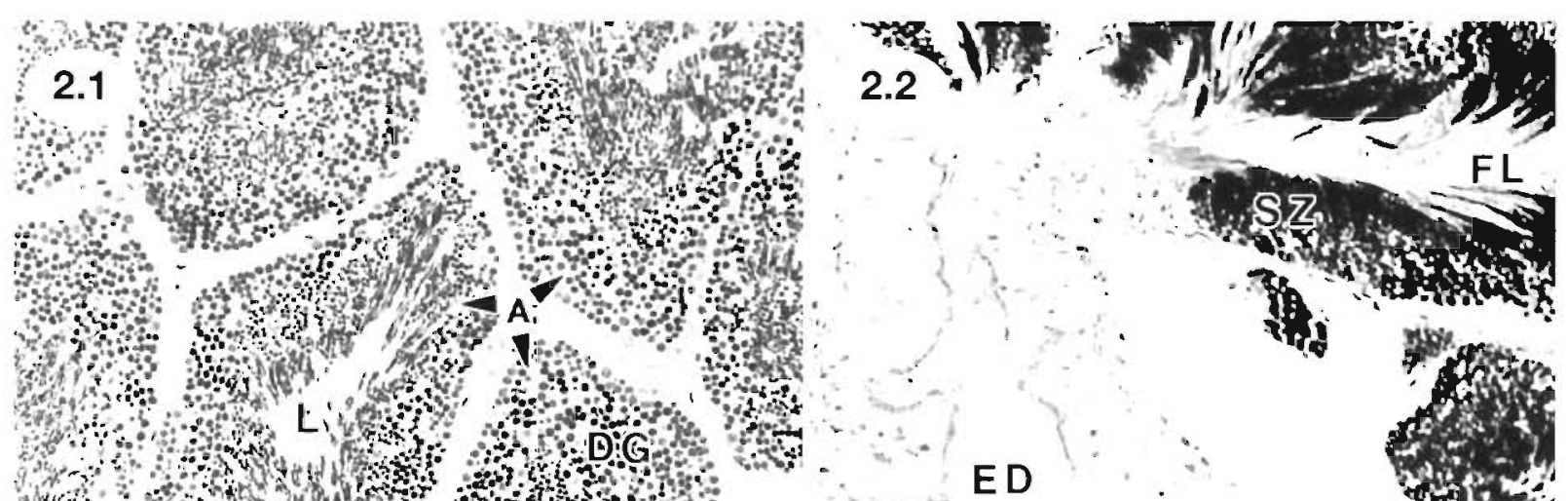

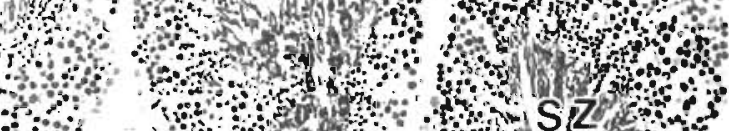

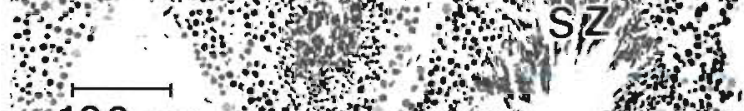
$100 \mu \mathrm{m}$ ond

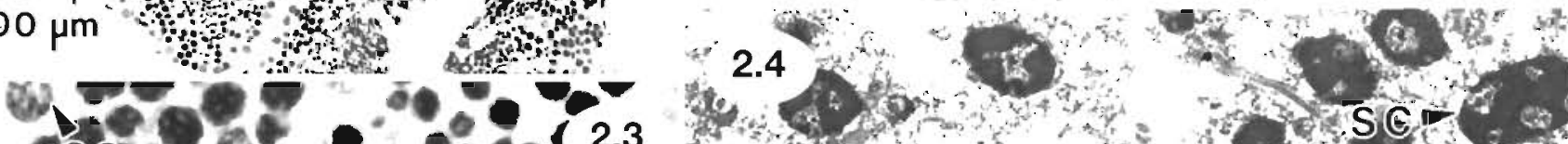
elsGu el

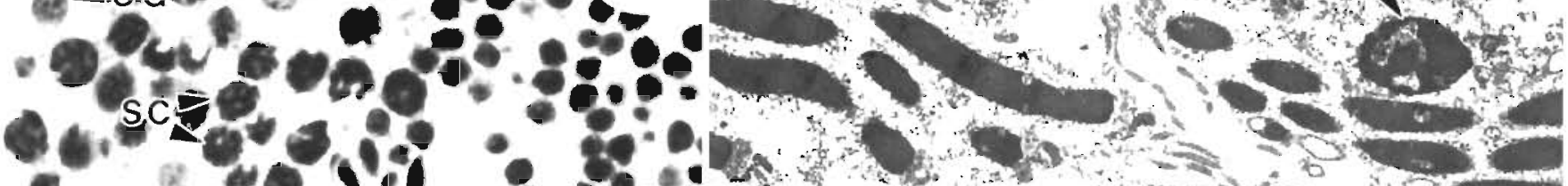

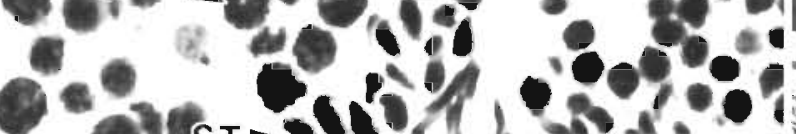

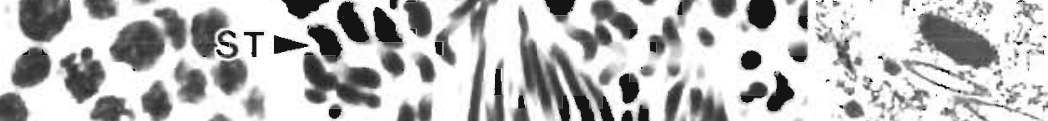

E D

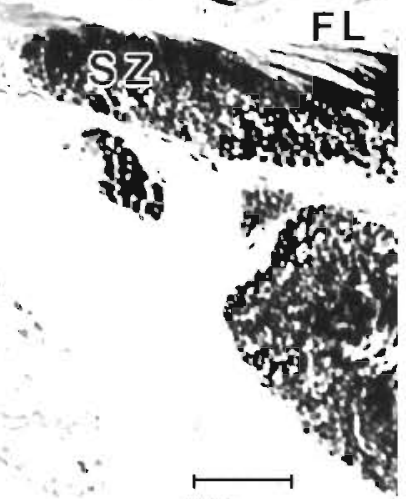

$60 \mu \mathrm{m}$

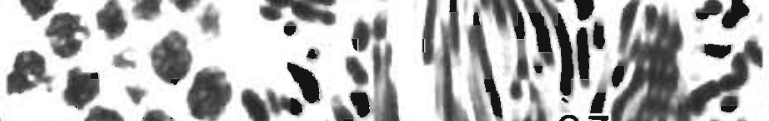

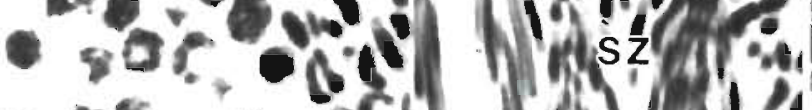

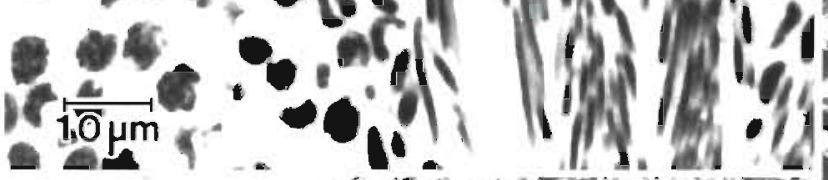

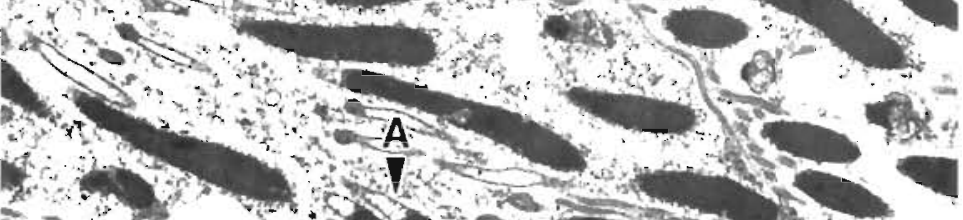

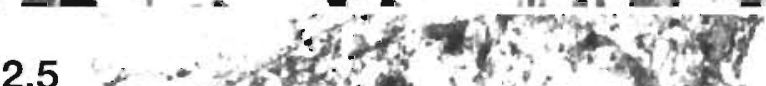

$2.5+40$.

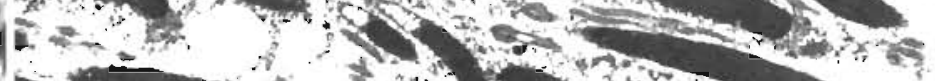

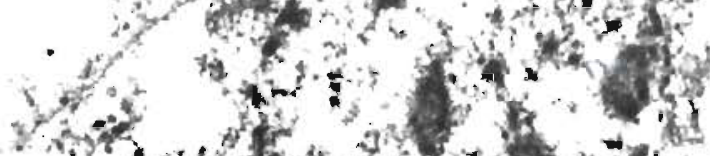

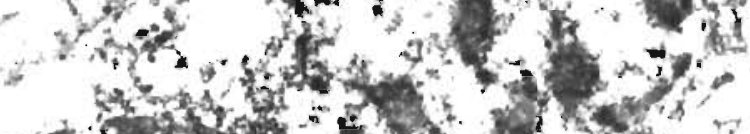

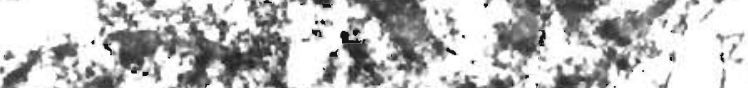

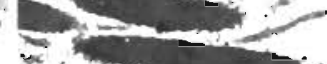

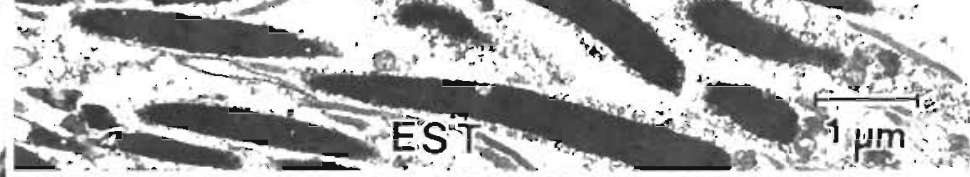

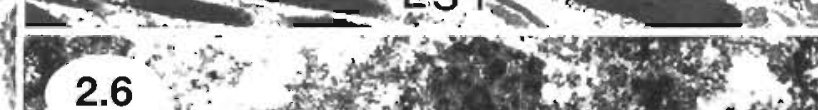

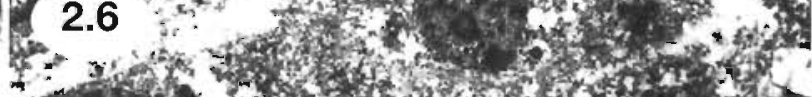

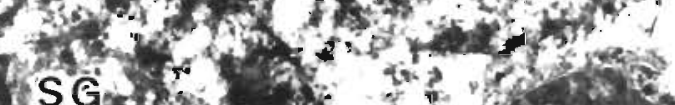

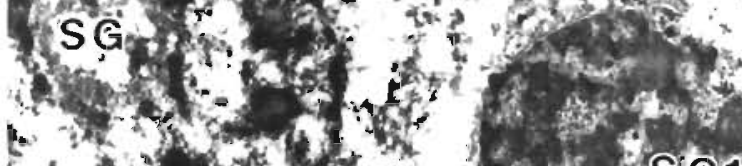

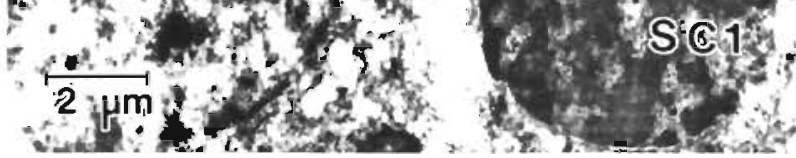

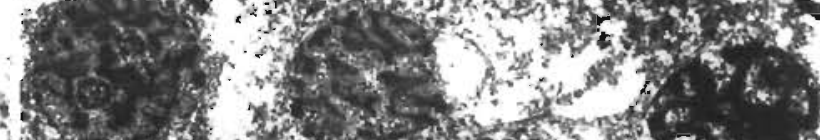

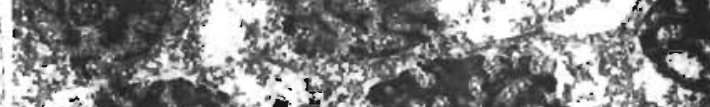

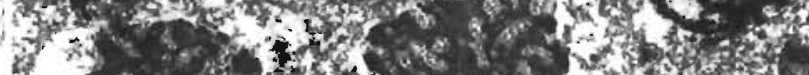

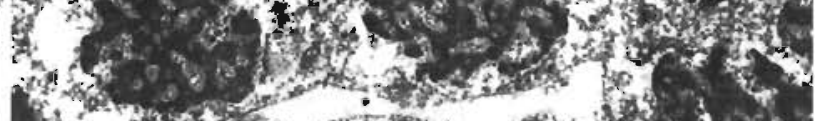

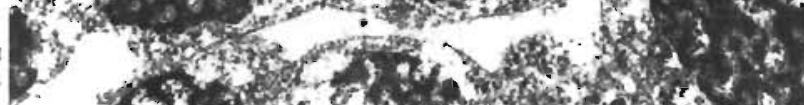

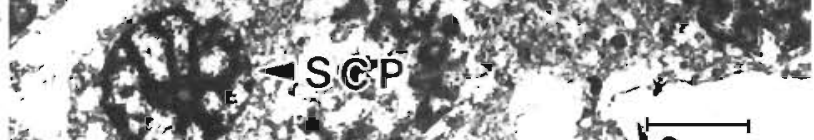
s. 


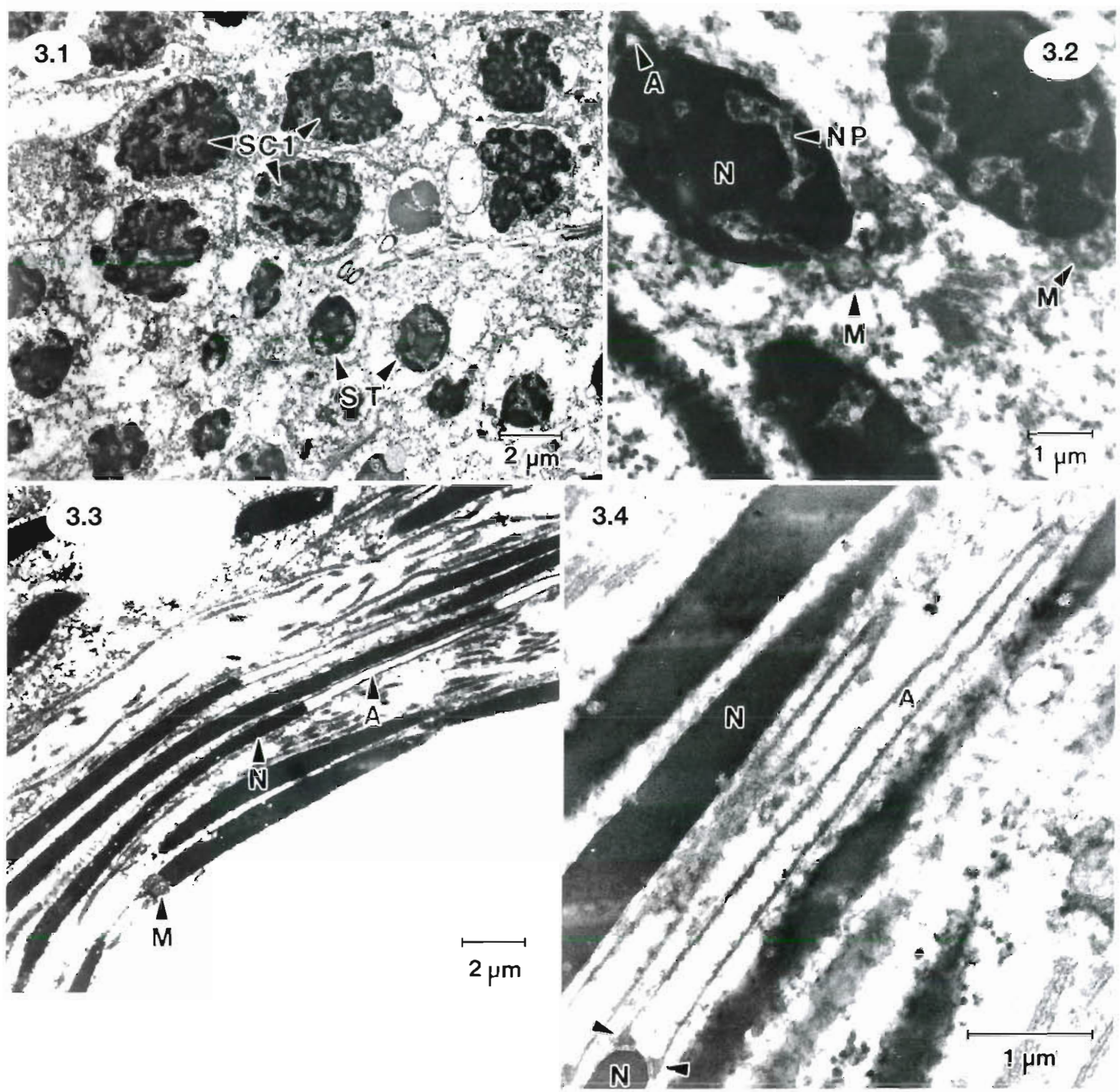

Fig. 3. Acharax alinae. Male gametogenic cell types. (3.1) Transition from primary spermatocytes (SC1) to early spermatids (ST) Note decrease in size and round aspect of these early spermatids. (3.2) Beginning of spermiogenesis, with mitochondrial collar (M) at basal pole ol spermatid, and formation of acrosome (A) at apical pole. Nucleus (N) highly condensed, with some patches of nucleoplasm (NP). (3.3) Mature spermatozoa, showing great elongation and curvature. (3.4) Detail of the junction between nucleus $(\mathrm{N}$ ) and acrosome (A). Note typical pyramidal structures (arrowheads)

tional specimens is unlikely, even in the event of a second expedition to the same sampling site, since Acharax alinae is endobenthic and not readily visible. While the probability that these are atypical specimens is low, it cannot be totally disregarded. We are un- aware, however, of any previous study which reported atypically large gametes in individuals from samples, and this has also been our own experience in work on a large number of samples from several different species. 


\section{General anatomical organization}

The anatomical organization of the bivalve gonad, including the coastal cryptodont Solemya reidi, consists of acini and anastomatosing gonoducts (Franc 1960, De Jong-Brink et al. 1983, Gustafson et al. 1987). The tubular form of the female Acharax alinae acini corresponds to the ellipsoid shape of the maturing oocytes, and is thus related to the packaging of the extraordinarily large gametes in the gonad of this species.

The bivalve gonad normally contains reserve tissue between the acini; the proportion of this tissue shows a reciprocal relationship to gamete development (Coe 1943, Lubet et al. 1976, Beninger 1987). The lack of reserve tissue in Acharax alinae suggests either that in this individual all such reserves were depleted, or that metabolite transfer to the developing oocytes is accomplished exclusively via other mechanisms (e.g. circulating haemocytes - see Le Pennec et al. 1991). The complete lack of reserve tissue contrasts with the situation found in the male gonad of 3 species of the hydrothermal vent genus Bathymodiolus (Le Pennec \& Beninger 1997), where inter-acinal reserve tissue was found in various amounts depending on sampling date.

\section{Female gametes}

The presence of approximately equal numbers of female gametes in all stages of development indicates that spawning is continuous or at least repeatedly partial in this species. A similar observation was made by Berg (1985) for the hydrothermal vent vesicomyid clam Calyptogena magnifica, and by Gustafson et al. (1987) for the littoral reducing-sediment clam Solemya reidi. Too little is known of reproductive dynamics in deep-sea reducing environment bivalves to permit generalizations, however, since evidence for seasonality was found in 2 Calyptogena species from Monterey Canyon (Lisin et al. 1997).

The large size of the female gametes is remarkable. The first cells of the germ line, the oogonia, are as large or larger $(80 \mu \mathrm{m})$ than the mature oocytes of most bivalves (Table 1). Assuming a roughly elliptical shape within the elongated gonad acini, the equivalent circular TEM micrograph diameter of fixed, mature oocytes can be calculated using the formula

$$
d=\sqrt{a \times b}
$$

where $d$ is the circular diameter and $a, b$ are the lengths of the major and minor elliptical axes. The resulting diameter for Acharax alinae oocytes up to $900 \times 400 \mu \mathrm{m}$ is $600 \mu \mathrm{m}$. A literature survey comprising 62 bivalve species, belonging to 30 families, 8 orders, and 5 of the 6 subclasses, shows that this diameter is 6.5 standard deviations from the overall mean oocyte diameter and 11 standard deviations from the mean of deep-sea bivalves from conventional habitats (Table 1). The largest size reported to date for littoral bivalve oocytes is Musculus discors at $300 \times 220 \mu \mathrm{m}$, or a spherical diameter of $257 \mu \mathrm{m}$ (Franzén 1983), while the largest diameter reported for any previous species was that of the hydrothermal vent clam Calyptogena magnifica (482 $\mu \mathrm{m}$; Berg 1985). Many of the oocyte diameters reported in Table 1 correspond to measures of spawned eggs, which were not subject to dehydration/embedding shrinkage. The deep folds observed in the cell membranes of $A$. alinae oocytes probably result from the elliptical distortion of oocytes which become spherical upon spawning. Assuming a dehydration/embedding shrinkage coefficient of $10 \%$ (Bozzola \& Russell 1992), the estimated diameter of spawned $A$. alinae eggs would be approximately $660 \mu \mathrm{m}$, dwarfing all other bivalve oocytes of which we are aware, including the contemporary littoral cryptodonts Solemya reidi and S. velum (Table 2 ).

With the exception of their large size and elongation, the female gametes of Acharax alinae presented the succession of gamete histological characteristics typical of oogenesis in bivalves from much more recent taxa: oogonia, previtellogenic oocytes, pedunculated oocytes, early and late vitellogenic oocytes, mature oocytes (Sastry 1979, Pipe 1987, Dorange \& Le Pennec 1989a, Beninger \& Le Pennec 1991, Eckelbarger \& Davis 1996).

\section{Male gametes}

In contrast to the oogonia, the spermatogonia size (diameter $7 \mu \mathrm{m}$ ) was similar to that reported for other bivalves (Sastry 1979, Dorange \& Le Pennec 1989b). The histological and ultrastructural profile of these cells was also similar to these data. The subsequent decrease in size of the primary spermatocytes and the spermatids is also quite typical of marine bivalves, as is their ultrastructural profile (Sastry 1979, Dorange \& Le Pennec 1989b). With the exception of the extreme elongation of the spermatid and spermatozoon, the attributes and stages of gametogenesis in Acharax alinae are similar to those of more contemporary bivalve taxa, indicative of conservation throughout the evolution of this class.

The length of the mature spermatozoon in Acharax alinae is unsurpassed in the entire bivalve class. A literature survey of 44 species from 17 families, 6 orders and 3 of the 4 subclasses other than the Cryptodonta shows the mean length and standard deviation of the head+midpiece to be $5.1 \pm 3.7 \mu \mathrm{m}$, while the 
Table 1. Maximum reported diameters for bivalve oncytes, S.C.: subclass; O.: order; F.: family. Acharax alinae was not included in calculations of mean $\pm \mathrm{SD}$ values

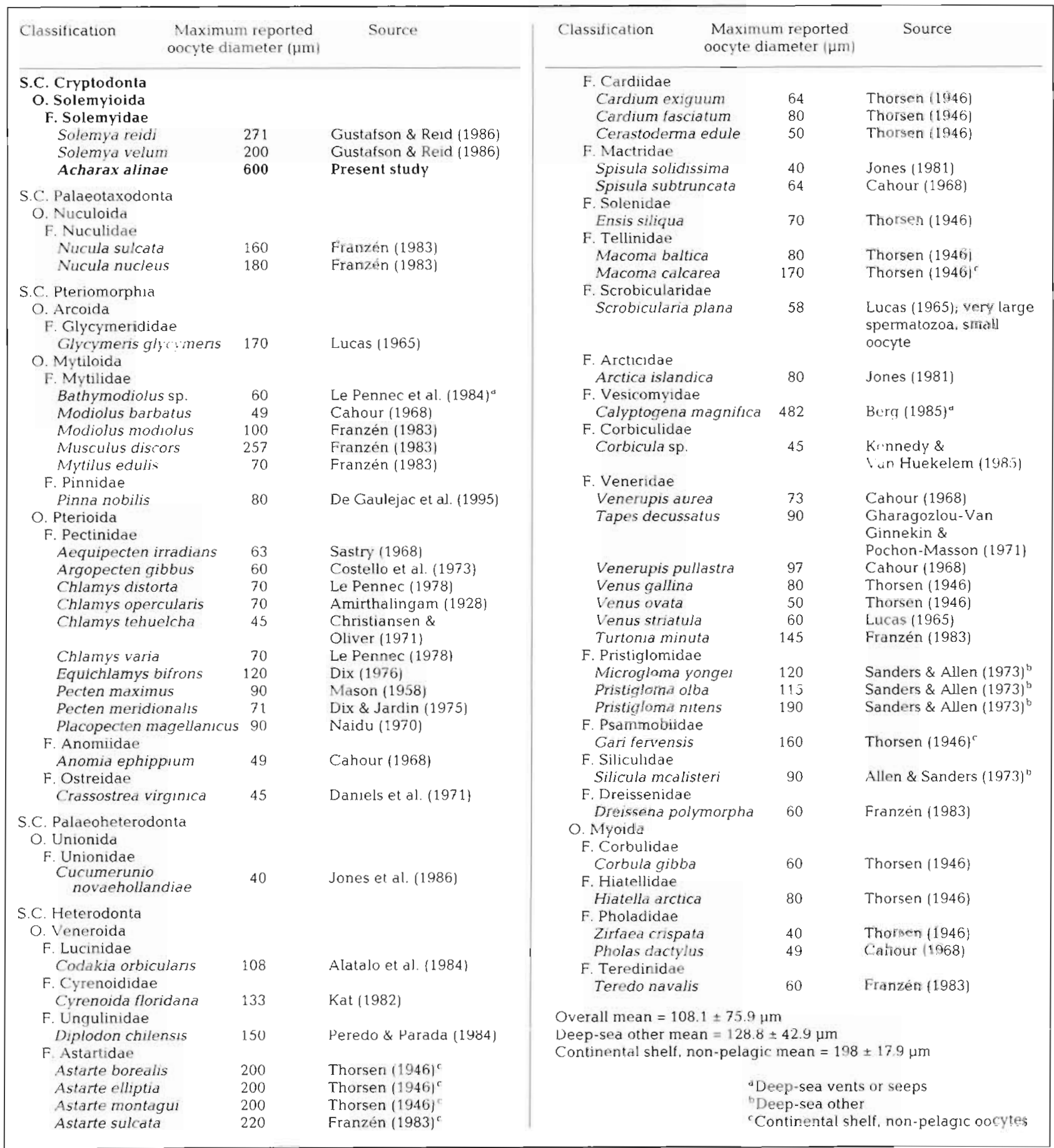

mean flagellum length is $34 \pm 17.1 \mu \mathrm{m}$. The largest dimensions reported to date are those of Scrobicularia plana, with a head+midpiece length of $23.6 \mu \mathrm{m}$ and a flagellum of $48 \mu \mathrm{m}$. (Sousa et al. 1989). These dimensions are dwarfed by those of $A$. alinae, with a head+midpiece length of $28 \mu \mathrm{m}$ and a flagellum length of $100 \mu \mathrm{m}$. The dimensions for $A$, alinae are therefore 6.2 and 3.9 standard deviations from their respective means. Spermatozoon elongation has been shown to be correlated with large oocyte size, which itself is correlated with lecithotrophic larval development [Franzén 1983; although $S$. plana appears to be an 
Table 2. Maximum reported lengths ( $\mu \mathrm{m}$ ) for bivalve spermatozoa. Acharax alinae was not included in calculations of mean \pm SD values

\begin{tabular}{|c|c|c|c|c|}
\hline Classification & $\begin{array}{l}\text { Maximum } \\
\text { total length }\end{array}$ & $\begin{array}{l}\text { Maximum length of } \\
\text { head+midpiece }\end{array}$ & $\begin{array}{l}\text { Maximum length } \\
\text { of flagellum }\end{array}$ & Source \\
\hline \multicolumn{5}{|l|}{ S.C. Cryptodonta } \\
\hline \multicolumn{5}{|l|}{$\begin{array}{l}\text { O. Solemyioida } \\
\text { F. Solemyidae }\end{array}$} \\
\hline Acharax alinae & 128 & 28 & 100 & Present study \\
\hline \multicolumn{5}{|l|}{ S.C. Palaeotaxodonta } \\
\hline \multicolumn{5}{|l|}{$\begin{array}{l}\text { O. Nuculoida } \\
\text { F. Nuculidae }\end{array}$} \\
\hline \multicolumn{2}{|l|}{ Nucula hartvigiana } & 7.5 & & Popham \& Marshall (1977) \\
\hline \multicolumn{2}{|l|}{ Nucula nucleus } & 8 & & Franzén (1983) \\
\hline \multirow{2}{*}{\multicolumn{2}{|c|}{$\begin{array}{l}\text { Nucula nudens } \\
\text { Nucula sulcata }\end{array}$}} & 8 & & Popham \& Marshall (1977) \\
\hline & & 9.2 & & Franzén (1983) \\
\hline \multirow{2}{*}{\multicolumn{5}{|c|}{$\begin{array}{l}\text { S.C. Pteriomorphia } \\
\text { O. Arcoida }\end{array}$}} \\
\hline & & & & \\
\hline \multirow{2}{*}{\multicolumn{2}{|c|}{ Barbiata follata }} & & & \\
\hline & & $\begin{array}{l}3 \\
3\end{array}$ & & Reunov \& Hodgson (1994) \\
\hline \multicolumn{2}{|l|}{$\begin{array}{l}\text { Barbata obnquata } \\
\text { F. Glycymerndidae }\end{array}$} & & & Feunov a hoagson (1994) \\
\hline Glycymeris glycymens & & 7.2 & & Lucas (1965) \\
\hline O. Mytiloida & & & & \\
\hline F. Mytilidae & & & & \\
\hline Arcuatula capensis & & 2.3 & & Reunov \& Hodgson (1994) \\
\hline Bathymodiolus elongatus & & 4 & & Le Pennec \& Beninger (1997) ${ }^{\mathrm{A}}$ \\
\hline Bathymodiolus puteoserpenti & & 3.8 & & Le Pennec \& Beninger (1997) \\
\hline Bathymodiolus thermophilus & & 3.6 & & Le Pennec \& Beninger (1997) a \\
\hline Brachiodontes semistriatus & & 4.5 & & Reunov \& Hodgson (1994) \\
\hline Modiolus barbatus & & 4 & & Cahour (1968) \\
\hline Modiolus modiolus & & 2 & & Franzén (1983) \\
\hline Choromytilus meridionalis & 50 & 4.2 & 45.8 & Hodgson \& Bernard (1986) \\
\hline Mytilus galloprovincialis & 50 & 6.4 & 43.6 & Hodgson \& Bernard (1986) \\
\hline Aulacomya ater & 55 & 7 & 48 & Hodgson \& Bernard (1986) \\
\hline Musculus discors & & 8.3 & & Franzén (1983) \\
\hline Mytilus edulis & & 2.5 & & Franzén (1983) \\
\hline O. Ptérioida & & & & \\
\hline F. Pteriidae & & & & \\
\hline Pinctada albina & 23.5 & 2.5 & 21 & Tranter (1959) \\
\hline F. Pectınidae & & & & \\
\hline Chlamys distorta & 47 & 2 & 45 & Lucas $(1965)$ \\
\hline Chlamys varia & & 2 & & Reddiah (1962) \\
\hline Pecten maximus & & 2 & & Dorange \& Le Pennec (1989b) \\
\hline Placopecten magellanicus & & 1.5 & & Naidu $(1970)$ \\
\hline F. Anomiidae & & & & \\
\hline Anomia ephipplum & & 3 & & Cahour (1968) \\
\hline F. Ostreidae & & & & \\
\hline Crassostrea virginica & & 2 & & Franzén (1983) \\
\hline S.C. Heterodonta & & & & \\
\hline $\begin{array}{l}\text { O. Veneroida } \\
\text { F. Astartidae }\end{array}$ & & & & \\
\hline $\begin{array}{l}\text { F. Astartidae } \\
\text { Astarte sulcata }\end{array}$ & & 10.5 & & Franzén (1983) \\
\hline F. Cardiidae & & & & \\
\hline Cerastoderma edule & & 6 & & Cahour (1968) \\
\hline $\begin{array}{l}\text { F. Mactridae } \\
\text { Spisula subtruncata }\end{array}$ & & & & Cahour (1968) \\
\hline $\begin{array}{l}\text { Spisula subtruncata } \\
\text { F. Scrobiculariidae }\end{array}$ & & 4 & & Canoul $(1900)$ \\
\hline Scrobicularia plana & 71.6 & 23.6 & 48 & $\begin{array}{l}\text { Sousa et al. (1989); } \\
\text { very large spermatozoa, small oocyte }\end{array}$ \\
\hline F. Dreissenidae & & & & \\
\hline Dreissena bugonsis & & 4.7 & & Denson \& Wang (1994) \\
\hline Dreissena polymorpha & & 2.8 & & Franzén (1983) \\
\hline F. Vesicomyidae & & & & \\
\hline Calyptogena magnifica & 11.5 & 3 & 8.5 & Le Pennec unpub]. ${ }^{a}$ \\
\hline Calyptogena pacifica & 15.5 & 3.5 & 12 & Le Pennec unpubl. ${ }^{a}$ \\
\hline F. Corbiculidae & & & & \\
\hline $\begin{array}{l}\text { Corbicula sp. } \\
\text { F. Veneridae }\end{array}$ & & 2.5 & & Kennedy \& Van Heukelem (1985) \\
\hline $\begin{array}{l}\text { F. Veneridae } \\
\text { Tivela polita }\end{array}$ & & & & \\
\hline $\begin{array}{l}\text { Tivela polita } \\
\text { Venerupis aurea }\end{array}$ & & 3.2 & & Reunov \& Hodgson (1994) \\
\hline $\begin{array}{l}\text { Venerupis aurea } \\
\text { Veperupis corrugata }\end{array}$ & & 5 & & Cahour (1968) \\
\hline Venerupis corrugata & & 3.7 & & Franzén (1983) \\
\hline Venerupis pullastra & & 5 & & Cahour (1968) \\
\hline Venerupis thomboudes & & 3.8 & & Franzén (1983) \\
\hline Tapes decussatus & & 7.9 & & Franzén (1983) \\
\hline Venus stratula & & 7 & & Franzén (1983) \\
\hline Turtonia minuta & & 10.5 & & Franzén (1983) \\
\hline O Myoida & & & & \\
\hline $\begin{array}{l}\text { F. Pholadidae } \\
\text { Pholas dactylus }\end{array}$ & & & & \\
\hline Pholas dactylus & & 5 & & Cahous (1968) \\
\hline Overall mean: head + midplece $=5$. & $1 \pm 3.7 \mu \mathrm{m}$, fla & $\mathrm{m}=34 \pm 17.1 \mu \mathrm{m}$ & & `Deep-sea vents or seeps \\
\hline
\end{tabular}


exception to this rule (Table 2)]. The unusually large size of the spermatozoon in A. alinae is thus probably a co-evolutionary consequence of the extremely large oocyte size

\section{Phylogenetic considerations}

The structure of the spermatozoon of Acharax alinae does not resemble any of the basic types described for the other bivalve subclasses (Popham 1979, Hodgson \& Bernard 1986), reinforcing the status of the Cryptodonta as a distinct subclass. Further studies on other Solemyidae, including the use of silver staining (Sousa et al. 1995), might provide additional insights.

The spermatozoon of the primitive protobranch Nucula spp. (Subclass Palaeotaxodonta, Order Nuculoida) is elongated but much smaller ( 7.5 to $11.7 \mu \mathrm{m})$; the acrosome is cap-shaped rather than elongated (Popham \& Marshall 1977, Franzén 1983). The spermatozoon of Dreissena bugonsis (Subclass Heterodonta, Order Veneroida) is slightly elongated and curved, but is also much smaller (head+midpiece $=4.7 \mu \mathrm{m}$ ), and the acrosome is not elongated (Denson \& Wang 1994). Furthermore, spermatozoon curvature does not appear to be a distinguishing taxonomic characteristic above the species level, as the spermatozoon of $D$. polymorpha is uncurved (Denson \& Wang 1994).

Although the spermatozoon of Scrobicularia plana (Subclass Heterodonta, Order Veneroida) has a head. midpiece region which is only $5 \mu \mathrm{m}$ shorter than that of Acharax alinae, as well as an elongated acrosome, its structure is very different, having highly unusual perinuclear mitochondria (Sousa et al. 1989, Healy 1996). It is thus apparent that nuclear and acrosome elongation are also not useful taxonomic criteria, being related to developmental strategy (Franzén 1983) rather than phylogenetic position. More generally, we may conclude that while the analysis of spermatozoon characteristics has proven to be a useful tool in taxonomy and phylogeny, it should be used with great prudence when comparing taxa presenting different developmental strategies.

\section{Hypotheses arising from gamete size}

As mentioned above, large oocyte size is traditionally associated with lecithotrophic development, i.e. either a very brief planktonic larval stage or direct development, either benthic or in a brooding female (Sastry 1979, Franzén 1983). While this interpretation holds true for 'conventional' littoral habitats, deep-sea reducing habitats present a very different constellation of parameters to which the associated fauna are adapted to different degrees (Le Pennec et al. 1995), requiring re-assessment of the adaptive value of developmental strategies in these environments (Mullineaux \& France 1995). Given that the pericalymma larva of the Solemyidae is a non-feeding stage in which development is essentially direct within an autonomous ciliated test (Gustafson \& Reid 1988), extensive reserves would enable a prolonged larval stage (direct absoption of dissolved organic matter or bacterial capture by the ciliated test epithelium would probably provide more sustenance for the test than the enclosed developing larva). In all likelihood, the extraordinarily large and vitellus-rich eggs of Acharax alinae are thus an adaptation for extended lecithotrophic development in the deep demersal environment. The longevity of the larval stage could be further extended by other mechanisms such as the low temperature of the deep-sea environment (Mullineaux \& France 1995). The only available data on larval development in Cryptodonta is for the littoral species Solemya reidi (Gustafson \& Reid 1988). The pericalymma larva of this species have a short larval period of $5 \mathrm{~d}$ in the laboratory. However, like the very short larval lives of the lecithotrophic Pandoridae (Subclass Anomalodesmata), this may be an adaptation to limit dispersal in species requiring highly localized but temporally stable habitats (Allen 1961, Boss \& Merrill 1965). In contrast, the unspawned oocyte of $A$. alinae is twice the size of that in $S$. reidi, and thrice that in $S$. velum (Table 2), suggesting a much longer lecithotrophic larval stage. An extended demersal stage would allow either increased dispersal or protracted benthic development. It should be noted that the single prodissoconch of $A$. alinae is also unusually large among the Bivalvia: $1.35 \times 0.68 \mathrm{~mm}$ (Métivier \& von Cosel 1993), demonstrating a very large larval size (see Le Pennec 1978, 1980 and Gustafson \& Reid 1986 for prodissoconch sizes in bivalves). Unfortunately, as in other cryptodonts there is no distinction between prodissoconchs I and II, so relative sizes of these structures cannot be used to verify the hypothesis of extended lecithotrophy (Turner et al. 1985).

Extended lecithotrophic development appears characteristic of some ancient lineages, as well as those groups which exploit an unusual habitat (Blacknell \& Ansell 1974). This of course raises the interesting and as yet unanswered question of whether bivalves and other metazoans initially evolved in reducing habitats, especially geologically active vents (Corliss et al. 1981, Baross \& Hoffman 1985, Nisbet 1985). The existence of relict species such as Bathypecten vulcani (Le Pennec et al. 1988), and the chronological correspondence between the extensive degree of geological activity of the earth's crust and the appearance of most of the major invertebrate taxa do indeed support this idea (see Tunnicliffe 1991). 
The present study of the gonad and gametes of Acharax alinae has elucidated several fundamental aspects of the reproductive biology of this primitive bivalve from deep-sea reducing habitat. The questions and hypotheses it raises are complex and intriguing. with repercussions for the understanding not only of abyssal reducing habitat fauna, but also of contemporary taxa of bivalves in conventional habitats.

Acknowledgements. We thank the Institut Français pour la Recherche et l'Exploitation de la Mer (IFREMER) and Mission Head A. M. Alayse-Danet for conducting the Biolau cruise during which the Acharax alinae specimens were sampled. We are grateful to A. Herry for technical assistance, and L. Blanchard for photographic expertise. S. C. Dufour assisted with data presentation in Tables 1 \& 2. This work was funded in part by a Natural Sciences and Engineering Research Council operating grant to P.G.B.

\section{LITERATURE CITED}

Alatalo P, Berg CJ, D'Asaro CN (1984) Reproduction and development in the lucinid clam Codakia orbicularis (Linné, 1758). Bull Mar Sci 34:424-434

Allen JA (1961) The development of Pandora inaequivalvis (Linné). J Embryol Exp Morphol 9:252-268

Allen JA, Sanders HL. (1973) Studies on deep-sea Protobranchia (Bivalvia). The families Siliculidae and Lametilidae. Bull Mus Comp Zool Harv Univ 145:263-310

Amirthalingam $C(1928)$ On lunar periodicity in reproduction of Pecten opercularis near Plymouth in 1927-28. J Mar Biol Assoc UK 15:605-641

Baross JA, Hoffman SE (1985) Submarine hydrothermal vents and associated gradient environments as sites for the origin and evolution of life. Origins Life 15:327-345

Beninger PG (1987) A qualitative and quantitative study of the reproductive cycle of the giant scallop, Placopecten magellanicus, in the Bay of Fundy (New Brunswick, Canada). Can J Zool 65:495-498

Beninger PG, Le Pennec M (1991) Functional anatomy of scallops. In: Shumway $S$ (ed) Scallops: biology, ecology and aquaculture. Elsevier, Amsterdam, p 133-223

Berg CJ (1985) Reproductive strategies of mollusks from abyssal hydrothermal vent communities. Bull Biol Soc Wash 6:185-197

Blacknell WM, Ansell. AD (1974) The direct development of Bivalve Thyasira gouldi (Philippi). Thalassia Jugosl 10 $23-43$

Boss KJ, Merrill AS (1965) The family Pandoridae in the Western Atlantic. Johnsonia 4:181-215

Bozzola JJ, Russell LD (1992) Electron microscopy: principles and techniques for biologists. Jones and Bartlett Publishers, Boston

Cahour A (1968) Cycle de reproduction et sexualite de huit espèces de Mollusques Bivalves. Mémoire de DES, Faculté des Sclences, Université de Bretagne Occidentale, p 1-33

Cavanaugh CM (1985) Symbioses of chemoautotrophic bacteria and marine invertebrates from hydrothermal vents and reducing sediments. Bull Biol Soc Wash 6:373-388

Childress JJ, Fisher CR (1992) The biology of hydrothermal vent animals: physiology, biochemistry, and autotrophic symbioses. Oceanogr Mar Biol Annu Rev 30:337-441
Christiansen HR, Oliver SR (1971) Sobre el hermaphroditismo de Chlamys tehuelcha D'orb. 1846. (Pelecypoda, Filibranchia, Pectinidae). An Soc Cient Argent 3:115-127

Coe WR (1943) Development of the primary gonads and differentiation of sexuality in Teredo navalis and other pelecypod mollusks. Biol Bull Mar Biol Lab Woods Hole 84: $178-187$

Corliss JB, Baross JA, Hoffman SE (1981) An hypothesis concerning the relationship between submarine hot springs and the origin of life on earth. Oceanol Acta Spec Issue 1:58-69

Costello TJ, Hudson MJ, Dupuy JL, Rivkin S (1973) Larval culture of the calico scallop Argopecten gibbus. Proc Natl Shellfish Assoc 63:72-76

Daniels EW, Longwell AC, MCNiff JM, Wolfgang RW (1971) Ultrastructure of the spermatozoa from the American oyster Crassostrea virginica. Trans Am Microsc Soc 90:275-282

De Gaulejac B, Henry M, Vicente N (1995) An ultrastructural study of gametogenesis of the marine bivalve Pinna nobilis (Linneaus 1758). l. Oogenesis. J Molluscan Stud 61:375-392

De Jong-Brink M, Boer HH, Joose J (1983) Mollusca. In: Adiyodi $\mathrm{KG}$, Adiyodi RG (eds) Reproductive biology of invertebrates, Vol I. Oogenesis, oviposition, and oosorption. John Wiley \& Sons Ltd, Chichester, p 297-355

Denson DR, Wang SY (1994) Morphological differences between zebra and quagga mussel spermatozoa. Am Malacol Bull 11:79-81

Dix TG (1976) Larval development of the queen scallop Equichlamys bifrons. Aust J Mar Freshwat Res 27:399-403

Dix TG, Jardin S (1975) Larvae of the commercial scallop, Pecten meridionalis from Tasmania, Australia. Aust J Mar Freshwat Res 26:109-112

Dorange G, Le Pennec M (1989a) Ultrastructural characteristics of oogenesis and oocytic degeneration in Pecten maximus (Mollusca, Bivalvia). Mar Biol 103:339-348

Dorange $G$, Le Pennec M (1989b) Ultrastructural characteristics of spermatogenesis in Pecten maximus (Mollusca, Bivalvia). J Invertebr Reprod Dev 15:109-117

Eckelbarger KJ, Davis CV (1996) Ultrastructure of the gonad and gametogenesis in the eastern oyster, Crassostrea virginica. I. Ovary and oogenesis. Mar Biol 127:79-87

Franc A (1960) Classe des Bivalves. In: Grassé PP (ed) Traité de zoologie, Tome 5, fascicule 2. Librairie Masson, Paris, p $1845-2133$

Franzén A (1970) Phylogenetic aspects of the morphology of the spermatozoa and spermiogenesis. In: Baretti B (ed) Comparative spermatology. Academic Press, New York, p $29-46$

Franzén A (1983) Ultrastructural studies of spermatozoa in three bivalve species with notes on evolution of elongated sperm nucleus in primitive spermatozoa. Gamete Res 7: $199-214$

Gharagozlou-Van Ginnekin ID, Pochon-Masson J (1971) Etude comparative infrastructurale du spermatozoide chez les palourdes de France. Arch Zool Exp Gen 112:805-817

Gustafson RG, Gustafson BD, Reid RGB (1987) Continuous reproduction in the protobranch bivalve Solemya reidi (Cryptodonta: Solemyidae). Veliger 29:367-373

Gustafson RG, Reid RGB (1986) Development of the pericalymma larva of Solemya reidi Bernard 1980 (Bivalvia, Cryptodonta, Solemyidae) as revealed by light and electron microscopy. Mar Biol 93:411-427

Gustafson RG, Reid RGB (1988) Larval and post-larval morphogenesis in the gutless protobranch bivalve Solemya reidi (Cryptodonta: Solemyidae). Mar Biol 97:373-387

Healy JM (1989) Spermiogenesis and spermatozoa in the relict bivalve genus Neotrigonia: relevance to trigo- 
nioid relationships, particularly Unionoidea. Mar Biol 103: $75-85$

Healy JM (1996) Molluscan sperm ultrastructure: correlation with taxonomic units within the Gastropoda, Cephalopoda, and Bivalvia. In: Taylor I (ed) Origin and evolutionary radiation of the Mollusca. Oxford University Press, Oxford, p 99-113

Hodgson AN, Bernard RTF (1986) Ultrastructure of the sperm and spermatogenesis of three species of Mytilidae (Mollusca, Bivalvia). Gamete Res 15:123-135

Jamieson BGM, Ausio J, Justine JL (1995) Advances in spermatozoal phylogeny and taxonomy. Mémoires du muséum national. d'histoire naturelle, Tome 166. Editions du Muséum, Paris

Jones DS (1981) Reproductive cycles of the Atlantic surf clam Spisula solidissima, and the ocean quahog Arctica islandica off New Jersey. J Shellfish Res 1:23-32

Jones HA, Simpson RD, Humphrey CL (1986) The reproductive cycles and glochidia of fresh-water mussels (Bivalvia: Hyriidae) of the Macleay River, Northern New South Wales, Australia. Malacologia 27:185-202

Kat PW (1982) Reproduction in a peripheral population of Cyrenoida floridana (Bivalvia: Cyrenoididae). Malacologia 23:47-54

Kennedy VS, Van Heukelem L (1985) Gametogenesis and larval production in a population of the introduced Asiatic clam, Corbicula sp. (Bivalvia: Corbiculidae) in Maryland. Biol Bull (Woods Hole) 168:50-60

Le Pennec M (1978) Genèse de lá coquille larvaire et postlarvaire chez divers Bivalves marins. Thèse de doctorat d'Etat, Université de Bretagne Occidentale

Le Pennec M (1980) The larval and post-larval hinge of some families of bivalve molluscs. J Mar Biol Assoc UK 60 : 601-617

Le Pennec M, Beninger PG (1997) Ultrastructural characteristics of spermatogenesis in three species of deep-sea hydrothermal vent mytilids. Can J Zool 75:308-316

Le Pennec M, Beninger PG, Dorange G, Paulet YM (1991) Trophic sources and pathways to the developing gametes of Pecten maximus (Bivalvia:Pectinidae). J Mar Biol Assoc UK 71:451-463

Le Pennec M, Beninger PG, Herry A (1995) Feeding and digestive adaptations of bivalve molluses to sulphide-rich habitats. Comp Biochem Physiol 111A:183-189

Le Pennec M, Herry A, Lutz R, Fiala-Médioni A (1988) Premières observations ultrastructurales de la branchie d'un Bivalve Pectinidae hydrothermal profond. C R Acad Sci Paris Sér III 307:627-633

Le Pennec M, Hily A, Lucas A (1984) Structures gonadiques particulières d'un Mytilidae profond des sources hydrothermales du Pacifique oriental. C R Acad Sci Paris Sér III 299:725-730

Lisin SE, Hannan EE, Kochevar RE, Harrold C, Barry JP (1997) Temporal variation in gametogenic cycles of ves1comyid clams. Invertebr Reprod Dev 31:307-318

Lubet P. Herlin P, Mathieu M, Collin F (1976) Tissu de réserve et cycle sexuel chez les Lamellibranches. Haliotis 7:59-62

Lucas A (1965) Recherches sur la sexualité des Mollusques Bivalves. Bull Biol Fr Belg 99:115-247

Mason J (1958) The breeding of the scallop Pecten maximus (L.), in Manx waters. J Mar Biol Assoc UK 37:653-671

Maxwell WL (1983) Mollusca. In: Adiyodi KG, Adiyodi RG (eds) Reproductive biology of invertebrates, Vol II: Sper-

Editorial responsibility: Otto Kinne,

Oldendorf/Luhe, Germany matogenesis and sperm function. John Wiley \& Sons Ltd, Chichester, p 275-319

Métivier B, von Cosel R (1993) Acharax alnae n. sp. Solemyidae (Mollusca: Bivalvia) géante du bassin de Lau. C R Acad Sci Paris Sér LII 316:229-237

Mullineaux LS, France SC (1.995) Dispersal mechanisms of deep-sea hydrothermal vent fauna. Geophys Monogr 91:408-424

Naidu KS (1970) Reproductuon and breeding cycle of the giant scallop Placopecten magellanicus (Gmelin) in Port au Port Bay, Newfoundland. Can J Zool 48:1003-1012

Nisbet EG (1985) The geological setting of the earliest life forms. J Mol Evol 21:289-298

Page HM, Fisher CR, Childress JJ (1990) Role of filter-feeding in the nutritional biology of a deep-sea mussel with methanotrophic symbionts. Mar Biol 104:251-257

Peredo S, Parada E (1984) Gonadal organization and gametogenesis in the fresh-water mussel Diplodon chilensis chilensis (Mollusca: Bivalvia). Veliger 27:126-133

Pipe RK (1987) Oogenesis in the marine mussel Mytilus edulis: an ultrastructural study. Mar Biol 95:405-414

Popham JD (1979) Comparative spermatozoon morphology and bivalve phylogeny. Malacol Rev 12:1-20

Popham JD, Marshall B (1977) The fine structure of the spermatozoon of the protobranch bivalve, Nucula hartvigiana Pfeiffer Veliger 19:431-433

Reddiah K (1962) The sexuality and spawning of manx pectinids. J Mar Biol Assoc UK 42:683-703

Reunov AA, Hodgson AN (1994) Ultrastructure of the spermatozoa of five species of South African bivalves (Mollusca), and an examination of early spermatogenesis. J Morphol 219:275-283

Sanders HL, Allen JA (1973) Studies on deep-sea Protobranchia (Bivalvia); Prologue and Pristiglomidae. Bull Mus Comp Zool Harv Univ 145:237-261

Sastry AN (1968) Relationships among food, temperature, and gonad development of the bay scallop. Aequipecten irradians concentricus Say, reared in the laboratory. Bull Mar Sci 15:417-435

Sastry AN (1979) Pelecypoda (excluding Ostreidae). In: Giese JC, Pearse JS (eds) Reproduction of marine invertebrates, Vol V. Academic Press, New York, p 113-292

Sousa M. Corral L, Azevedo C (1989) Ultrastructural and cytochemical study of spermatogenesis in Scrobicularia plana (Mollusca, Bivalvia). Gamete Res 24:393-401

Sousa M. Oliveira E, Carvalleiro J, Oliveira V (1995) Comparative silver staining of molluscan spermatozoa. In: Jamieson BGM. Ausio J, Justine JL (eds) Advances in spermatozoal phylogeny and taxonomy. Mém Mus Nat Hist Nat 166:179-187

Thorsen G (1946) Reproduction and larval development of Danish marine bottom invertebrates, with special reference to the planktonic larvae in the Sound (Øresund). Medd Komm Havundersag, Kbh, Ser Plankton 4:1-523

Tranter DJ (1959) Reproduction in Australian pearl oysters (Lamellibranchia). II Pinctada albina (Lamarck): gametogenesis. Aust J Mar Freshwat Res 9:144-158

Tunnicliffe V (1991) The biology of hydrothermal vents: ecology and evolution. Oceanogr Mar Biol Annu Rev 29: $319-407$

Turner RD, Lutz RA, Jablonski D (1985) Modes of molluscan larval development at deep-sea hydrothermal vents. Biol Soc Wash Bull 6:167-184

Submitted: February 14, 1997; Accepted: July 14, 1997

Proofs received from author(s): September 18, 1997 